\title{
Responses of hardwood regeneration to fire in mesic forest openings. III. Whole-plant growth, biomass distribution, and nitrogen and carbohydrate relations
}

\author{
Eric L. Kruger and Peter B. Reich
}

\begin{abstract}
The effects of fire on the carbon and nitrogen balance of northern red oak (Quercus rubra L.), white ash (Fraxinus americana L.), and sugar maple (Acer saccharum Marsh.) regeneration were studied in mesic openings in a hardwood forest. A plot in each of four openings was burned in the spring of both 1989 and 1990. Relative growth rate, leaf weight ratio, and concentrations of nonstructural carbohydrate and $\mathrm{N}$ were monitored on planted and extant regeneration in burned and nonburned plots. In the absence of fire, extant oak grew as rapidly as ash and maple, but the relative growth rate of planted oak was the lowest of any species or regeneration type. Repeated burning had little effect on the net growth of oak, but it decreased that of ash and maple by $24-85 \%$. Fire effects on relative growth rate were mediated primarily by changes in leaf weight ratio, but the causes underlying these changes were not fully elucidated. They were not consistent with trends in plant nonstructural carbohydrate or $\mathrm{N}$ concentration, which increased or remained unaffected after fire in all species. In general, oak possessed a number of characteristics, such as a high root starch concentration and an abundance of belowground dormant buds, which appeared to contribute to its post-fire vigor.
\end{abstract}

Résumé : Les effets du feu sur le bilan du carbone et de l'azote chez la régénération de chêne rouge (Quercus rubra L.), de frêne d'Amérique (Fraxinus americana L.) et d'érable à sucre (Acer saccharum Marsh.) ont été étudiés dans des ouvertures mésiques dans une forêt feuillue. Dans chacune des quatre ouvertures, une parcelle a été brûlée aux printemps en 1989 et 1990. Le taux relatif de croissance, le ratio du poids du feuillage et la concentration des hydrates de carbone non structuraux et de $\mathrm{N}$ ont été suivis chez la régénération artificielle et existante dans des parcelles brûlées et témoins. En l'absence de feu, la régénération existante de chêne se développait aussi rapidement que celle du frêne et de l'érable mais le taux relatif de croissance des chênes qui avaient été plantés était le plus faible de toutes les espèces et de tous les types de régénération. Le brûlage répété avait peu d'effet sur la croissance nette du chêne mais il diminuait la croissance du frêne et de l'érable de 24 à $85 \%$. Les effets du feu sur le taux relatif de croissance étaient dus principalement aux changements dans le ratio du poids du feuillage mais les causes à l'origine de ces changements n'ont pas été totalement éclaircies. Ils n'étaient pas consistents avec les tendances dans la concentration des hydrates de carbone non structuraux et de $\mathrm{N}$ dans les plants. En général, le chêne possède plusieurs caractéristiques, telles une forte concentration en amidon dans les racines et un grand nombre de bourgeons dormants souterrains, qui semblent contribuer à sa vigueur après feu.

[Traduit par la Rédaction]

\section{Introduction}

Prescribed burning may prove to be a useful tool in the regeneration of northern red oak (Quercus rubra L.) and its congeners, but uncertainty exists regarding the specific benefits of fire in this context, especially in mesic forests. Fire often has a differential impact on the survival of woody species, and northern red oak has been shown to be less negatively affected than some of its common associates in mesic forests (Brown 1960; Swan 1970). Little is known, however, about the influences of fire on competition among woody survivors, which

Received July 31, 1996. Accepted May 30, 1997.

E.L. Kruger. ${ }^{1}$ Department of Forestry, University of Wisconsin-Madison, 120 Russell Labs, 1630 Linden Avenue, Madison, WI 53706, U.S.A.

P.B. Reich. College of Forest Resources, University of Minnesota, St. Paul, MN 55108, U.S.A.

1 Author to whom all correspondence should be addressed. may play an important role in post-fire community development (Perala 1974; Busch and Smith 1993). In addition to its immediate impacts on plant size, fire may influence post-fire growth rate through changes in microenvironment and soil resource availability (Christensen 1987; Wellington 1984), as well as shifts in a plant's internal resource balance through the destruction of nutrient and carbohydrate reserves. Either singly or in combination, these effects can mediate changes in key growth determinants such as leaf photosynthesis (Reich et al. 1990).

In the absence of fire, northern red oak is frequently outcompeted by a number of woody species in mesic, high-light environments (e.g., Johnson 1976; Farmer 1981; Beck and Hooper 1986). Oak's poor competitive ability, characteristic of late-successional, shade-tolerant species (Bazzaz 1979; Walters et al. 1993), is combined with an apparent intolerance of understory environments in an enigmatic ecology, which seems to confine it to disturbance-related niches in mesic forests (Crow 1988; Abrams 1992; Johnson 1993; Lorimer 1993). At least as a seedling, red oak grows slowly because of a moderate 
leaf photosynthetic capacity, relatively thick leaves, and a biomass distribution pattern that is heavily skewed toward roots (Farmer 1980; Kolb and Steiner 1990; Walters et al. 1993). However, the causes underlying tree species variation in growth rate and competitive ability have been determined primarily for individuals grown in isolation under controlled conditions (Loach 1970; Farmer 1980; Walters et al. 1993). Recent studies have indicated that these assessments may not always reflect behavior in natural competitive environments (Kolb and Steiner 1990; Burton and Bazzaz 1995; Dillenburg et al. 1995).

This paper is one of a series examining the effects of fire on the physiology and growth of northern red oak and sympatric hardwood regeneration in mesic forest openings in southwestern Wisconsin. In a companion paper (Kruger and Reich 1997a), repeated annual burning enhanced oak's competitive status in these openings because, among several hardwood species, it suffered the least mortality and the smallest decrease in net height growth during the 2-year study. Fire also differentially affected the leaf function of red oak, sugar maple (Acer saccharum Marsh.), and white ash (Fraxinus americana L.) (Kruger and Reich 1997b). In particular, fire led to a relatively large increase in leaf photosynthesis of maple, with less pronounced effects occurring in oak and ash. Here we examined variation in biomass growth rate among these three species in the presence and absence of fire. Our principal objective was to explain this variation based on observed relationships between growth and a suite of attributes, including leaf weight ratio, specific leaf area, photosynthesis, and $\mathrm{N}$ and nonstructural carbohydrate relations.

\section{Materials and methods}

\section{Study sites and experimental design}

In April 1989 two 200- $\mathrm{m}^{2}$ plots were established in each of four 0.5-ha openings in mature, mesic hardwood stands on the Jordan Timberland, a private forest in the "Driftless" physiographic region (Braun $1950)$ of southwestern Wisconsin $\left(42^{\circ} 59^{\prime} \mathrm{N}, 90^{\circ} 07^{\prime} \mathrm{W}\right)$. Two openings were created on each of two north-facing slopes, and within these openings all woody stems with diameters greater than $2.5 \mathrm{~cm}$ at breast height $(1.37 \mathrm{~m})$ were removed. Soils on these sites were Typic Hapludalfs (Hole 1976), with a silt cap overlying a horizon of clay or clay and dolomite residuum. One randomly chosen plot in each opening was burned in early May of both 1989 and 1990. The other was left as a control. After the 1989 fire, each block was fenced $(2 \mathrm{~m}$ in height) to minimize herbivory by deer and other mammals. Additional information regarding the study site, experimental design, site manipulations, and treatments is given in Kruger and Reich (1997a).

\section{Growth measurements}

Growth was monitored on planted and extant regeneration of northern red oak, white ash, and sugar maple on burn and control plots in each opening. Planted regeneration was of two different origins, nursery seedlings and forest-grown individuals (see Kruger and Reich $1997 b$ ). Growth rates of planted individuals were determined from whole-plant harvests in the spring and fall of 1990. Plant dry mass initially varied by as much as 20 -fold within and across species and origins (e.g., 3 to $60 \mathrm{~g}$ for ash), and in order to account for this vari-

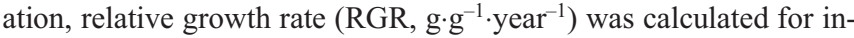
dividual plants, where RGR $=[\ln ($ harvest dry mass $)-\ln$ (initial dry mass)]/years (Evans 1972).

Measures of actual biomass gain on burn plots required an accounting for the initial stem mass destroyed by fire, whereas, from an ecological point of view, it was also relevant to compare treatment effects on net biomass gain. Therefore two different values of RGR were calculated on burn plots. Net RGR was derived using initial pre-burn mass (not adjusting for stem loss), while actual RGR was determined using an estimate of initial post-burn mass (subtracting stem loss). The latter was equivalent to initial root mass, which was estimated for individuals based on averages for root weight ratio (RWR) determined (1) for each species and origin on initial planting stock samples in 1989 and (2) for each species based on spring harvest data in 1990 (see below). Measures of pre-burn RWR in 1990 did not differ significantly across openings or plant origins.

With the exception of ash and maple on burn plots, two planted individuals (one per origin) of each species were harvested on every plot just prior to burning in the spring of 1990 . These plants were used for determining 1989 RGR and for assessing N and carbohydrate status at the time of the 1990 fire. Owing to high post-fire mortality (Table 1), only one ash or maple individual (either nursery or forest grown) was harvested per burn plot. In November 1990, three to five individuals of each species (varying numbers per origin) were harvested on a given plot. Once again maple on burn plots was an exception, as a total of seven planted maples (one to three per plot) were alive in the burn treatment in November, all of which were harvested. At harvest, roots were washed, and all materials were dried to a constant mass at $70^{\circ} \mathrm{C}$ and then weighed.

In both years, RGR of planted individuals was calculated using estimates of initial mass and direct measures of final mass. In 1989 , the fresh mass of each individual was measured before planting, and its initial dry mass was estimated using regressions of dry versus fresh mass generated for each species and origin, based on a random sample of 10 to 20 plants per species $\times$ origin (in all cases regression $r^{2}>0.95$, $p<0.0001$ ). Harvest data from spring 1990 were used to generate relationships between dry mass in 1990 and fresh mass in 1989 for each treatment $\times$ species combination (in all cases $r^{2}>0.80, p<0.0001$ ). These regressions, which did not differ with plant origin, were used to estimate initial mass in 1990. At no time during the study did growth differ significantly between origins, and thus growth data were pooled across origins in all analyses.

For extant regeneration, RGR was estimated using significant allometric relationships $\left(r^{2}>0.50, p<0.01\right)$ between the ln of plant dry mass and the $\ln$ of stem height derived with data from extant individuals of each species and treatment harvested in the spring of both years (Kruger 1992). When combined with species $\times$ plot averages for stem height (data from Kruger and Reich 1997a), these relationships allowed for the estimation of species $\times$ plot averages for plant mass and hence RGR in each year. Both net and actual RGR were calculated for extant regeneration on burn plots, and for actual RGR the adjustments in initial plant mass for stem loss were based on RWRs measured on harvested extant individuals.

\section{Measurement of biomass distribution during the 1990 growing season}

With the exception of ash on burn plots, two extant individuals per species were harvested from burn and control plots on July 1 and August 25, 1990. The low survivorship of extant ash on burn plots in 1990 precluded harvesting. At harvest, plants were separated into leaves, stems, and roots, and leaf area was measured with a LI-COR 3100 leaf area meter (LI-COR Inc., Lincoln, Nebr.). Roots were washed, and all organs were dried to a constant mass at $70^{\circ} \mathrm{C}$ and then weighed. These data were used to calculate leaf weight ratio (LWR, $\left.\mathrm{g} \cdot \mathrm{g}^{-1}\right)$.

LWR was also nondestructively estimated for planted individuals on June 20 and September 1, 1990. These values were generated with estimates of total leaf and nonleaf (stem + root) dry mass for every plant at each of the two dates. Total leaf mass was calculated as the quotient of total leaf area and a plot $\times$ species average for specific leaf area (SLA, $\left.\mathrm{m}^{2} \cdot \mathrm{kg}^{-1}\right)$ measured at or about each date that LWR was estimated (data from Kruger and Reich 1997b). Estimates of total leaf 
area were based on leaf counts along with measures of leaf length and width, which were converted to leaf area using species-specific calibration regressions ( $n=20$ leaves, $r^{2}>0.90$ for each species). Nonleaf mass was calculated for each individual as the sum of its initial postfire mass in 1990 and a mass increment, which was based on its 1990 RGR (plot $\times$ species average) and the proportion of the growing season that had passed at each date.

\section{Analysis of nonstructural carbohydrate and nitrogen relations} Concentrations of total nonstructural carbohydrates (TNC) were determined in nursery and forest-grown individuals harvested at the time of planting in 1989, and in extant and planted regeneration harvested in the spring and fall of 1990. Dried stem and root tissues were ground and measured separately for starch and soluble sugars using the methods described in Amundson et al. (1995). Tissue $\mathrm{N}$ was also measured in stems and roots of planted individuals harvested in the spring and fall of 1990. Dried tissue was ground and submitted to the Plant and Soil Analysis Lab at the University of Wisconsin-Madison, where total $\mathrm{N}$ was determined using a micro Kjeldahl procedure (Schulte et al. 1987).

Determinations of plant $\mathrm{N}$ dynamics in 1990 also required data on $\mathrm{N}$ retranslocation from senescing foliage. In the fall of 1990, leaves of ash, oak, and maple regeneration were collected on all plots within 7 days after abscission, measured for area, dried to a constant mass at $70^{\circ} \mathrm{C}$, weighed, ground, and measured for total N. The $\mathrm{N}$ per unit area (LNA, $\mathrm{g} \cdot \mathrm{m}^{-2}$ ) of leaf litter was calculated as the product of its $\mathrm{N}$ concentration $\left(\mathrm{g} \cdot \mathrm{g}^{-1}\right)$ and mass per unit area $\left(\mathrm{LMA}, \mathrm{g} \cdot \mathrm{m}^{-2}\right)$. Percent $\mathrm{N}$ retranslocation was then estimated for each species $\times$ plot as the difference between species $\times$ plot averages for litter LNA and seasonal maximum LNA (data from Kruger and Reich 1997b), expressed as a percent of seasonal maximum LNA.

Net $\mathrm{N}$ uptake $\left(\mathrm{mg} \mathrm{N} \cdot(\mathrm{g} \text { root })^{-1}\right)$ by planted individuals in 1990 was calculated by subtracting initial from final measures of plant $\mathrm{N}$ content (g N/plant) and dividing that difference by an estimated seasonal average for root mass. Total $\mathrm{N}$ uptake in 1990 was derived by summing net uptake and the estimated amount of $\mathrm{N}$ lost in leaf litter, and dividing this sum by average root mass. The amount of $\mathrm{N}$ lost in leaf litter was estimated for each individual based on seasonal maxima for plant leaf area and LNA, along with percent $\mathrm{N}$ retranslocation. Nitrogenuse efficiency (NUE, $g \cdot g^{-1}$ ) for planted individuals in 1990 was calculated according to Aerts (1990), where NUE was the product of the biomass production efficiency $\left(\mathrm{PE}, \mathrm{g}\right.$ biomass gain $\left.\cdot(\mathrm{g} \mathrm{N})^{-1} \cdot \mathrm{year}^{-1}\right)$ and mean residence time (MRT, year) of $\mathrm{N}$ in the plant. PE was the quotient of a plant's annual biomass gain and its average $\mathrm{N}$ content during the growing season. MRT was the quotient of the seasonal maximum for plant $\mathrm{N}$ content and the total $\mathrm{N}$ in leaf litter. In the absence of data on fine-root turnover, the contribution of belowground $\mathrm{N}$ loss was ignored in the NUE calculation.

\section{Analysis of relationships between RGR and its determinants}

Using data from extant as well as planted regeneration, we analyzed relationships between RGR and seasonal averages for LWR, SLA, and leaf photosynthesis in 1990. For LWR, a seasonal average was derived from the two measures or estimates for each regeneration type. Seasonal averages for light-saturated photosynthesis and SLA were taken from Kruger and Reich $(1997 b)$. These leaf properties were monitored on planted and extant individuals throughout the study, and they did not differ significantly between the two regeneration types. Therefore, the same leaf data were considered to be representative of planted as well as extant regeneration in this analysis.

Two photosynthetic parameters were analyzed for their roles in growth variation, a seasonal average for light-saturated photosynthesis $\left(A_{\max }, \mu \mathrm{mol} \cdot \mathrm{m}^{-2} \cdot \mathrm{s}^{-1}\right)$ and an estimate of daily average photosynthesis $\left(A_{\text {avg }}, \mu \mathrm{mol} \cdot \mathrm{m}^{-2} \cdot \mathrm{s}^{-1}\right)$ in midsummer. The latter incorporated the influence of a dynamic light environment and was based on photosynthetic light responses generated from in situ gas exchange measures on variably cloudy mornings in early August 1990 (Kruger 1992). Incident photosynthetic photon flux density (PPFD) during these measurements ranged from 80 to $1500 \mu \mathrm{mol} \cdot \mathrm{m}^{-2} \cdot \mathrm{s}^{-1}$. Light-response curves, based on individual leaf data collected from all openings, were created for each species $\times$ treatment using the model of Hanson et al. (1988). The model was driven by three parameters: light-saturated photosynthesis $\left(A_{\max }, \mu \mathrm{mol} \cdot \mathrm{m}^{-2} \cdot \mathrm{s}^{-1}\right)$, compensation PPFD $\left(\mathrm{LC}, \mu \mathrm{mol} \cdot \mathrm{m}^{-2} \cdot \mathrm{s}^{-1}\right)$, and dark respiration $\left(R_{\mathrm{d}}, \mu \mathrm{mol} \cdot \mathrm{m}^{-2} \cdot \mathrm{s}^{-1}\right)$, where $A_{\text {area }}=A_{\max }\left(1-\left(1-R_{\mathrm{d}} / A_{\max }\right)^{(1-(\mathrm{PPFD} / \mathrm{LC}))}\right)$. For control ash, $A_{\max }=11.1, \mathrm{LC}=15$, and $R_{\mathrm{d}}=0.9$; for burn ash, $A_{\max }=12.1, \mathrm{LC}=39$, and $R_{\mathrm{d}}=2.4$; for control oak, $A_{\max }=11.3$, $\mathrm{LC}=21$, and $R_{\mathrm{d}}=1.6$; for burn oak, $A_{\max }=11.8, \mathrm{LC}=25$, and $R_{\mathrm{d}}=1.2$; for control maple, $A_{\max }=5.2, \mathrm{LC}=27$, and $R_{\mathrm{d}}=1.4$; for burn maple, $A_{\text {max }}=6.6, \mathrm{LC}=35$, and $R_{\mathrm{d}}=2.7$.

As PPFD was not monitored in this study, its influence on photosynthesis was modelled with PPFD data collected in a forest opening similar in many characteristics (e.g., size, aspect, and vegetation structure) and in close proximity to the openings in this study (Kaelke 1996). These data were instantaneous values collected under variable conditions (about 50\% clear and 50\% cloudy) with a LI-COR quantum sensor attached to a LI-1000 data logger (LI-COR Inc, Lincoln, Nebr.) throughout a 7-day period in early August. Using photosynthetic light-response curves, an estimate of $A_{\text {area }}$ was generated for every PPFD measurement, and the average of these values $\left(A_{\text {avg }}\right)$ was determined for each species $\times$ treatment combination. A comparison of $A_{\text {avg }}$ with $A_{\max }$ revealed that the two were closely related: $A_{\text {avg }}=$ $1.9+0.35\left(A_{\max }\right), r^{2}=0.99, p<0.0001(n=6)$.

\section{Statistical analyses}

The effects of treatment, species, and their interaction were examined with analysis of variance (ANOVA) using the general linear models procedure (PROC GLM) in SAS (SAS Institute Inc. 1988). The study was set up as a split-plot design in a randomized complete block arrangement, treating plots as whole units and species as subunits. When the effect of blocking was not significant $(p>0.10)$ the data were analyzed as if the split plot was in a completely randomized arrangement. Relationships among continuous variables were analyzed with linear regression (PROC GLM). ANOVA, regressions, and differences among means were significant if $p \leq 0.05$.

Homogeneity of variance was tested with Levene's method (Milliken and Johnson 1989); when heteroscedasticity was found, the data were transformed (e.g., with natural logarithm) prior to ANOVA. Fisher's protected LSD was used to identify significant differences among species $\times$ treatment means. In accordance with the split-plot design, different LSDs were calculated for mean comparisons within and across treatments. The derivation of within-treatment LSDs was based on subunit error, while across-treatment LSDs were calculated based on a combination of subunit and whole-unit error (Milliken and Johnson 1989). In the case of LWR data, one treatment $\times$ species combination was missing, and therefore error terms and test statistics were calculated using the methods of Milliken and Johnson (1989) for missing subunits in a split-plot design.

RGR, LWR, and plant $\mathrm{N}$ concentration were negatively correlated with plant mass in this analysis. To account for this frequently observed (e.g., Walters et al. 1993) and often confounding influence of plant size, means of all three parameters were adjusted for variation in the $\ln$ of initial mass with analysis of covariance, using the LSMEANS procedure in PROC GLM. Within regeneration types, the slopes of these regressions did not differ significantly across species or treatments. In 1990, the RGR and LWR of planted individuals were not significantly related to initial mass and therefore their means were not adjusted.

\section{Results}

\section{Survival of planted regeneration}

The survival of planted oak and maple regeneration was poor on all plots during the 2-year study (Table 1). Nevertheless, 
Table 1. Percent survival of planted ash, oak, and maple regeneration on burn and control plots in 1989 and 1990 .

\begin{tabular}{lclc}
\hline & & \multicolumn{2}{c}{ Survival (\%) } \\
\cline { 3 - 4 } Species & Year & Control & Burn \\
\hline White ash & 1989 & $98(2) a$ & $39(8) c$ \\
& 1990 & $78(2) a$ & $21(6) c$ \\
Red oak & 1989 & $75(7) b$ & $76(5) b$ \\
& 1990 & $37(10) b c$ & $42(3) b$ \\
Sugar maple & 1989 & $66(5) b$ & $27(6) c$ \\
& 1990 & $44(5) b$ & $6(1) d$ \\
\hline
\end{tabular}

Note: Values are treatment means (with their standard errors) of the percentage of individuals planted in 1989 that were alive at the end of each year. Within years, means without common letters are significantly different at $p \leq 0.05$, based on an ANOVA using arcsine transformations of the data.

post-fire survival of planted individuals varied among species in a manner that was consistent with trends observed for extant regeneration (Kruger and Reich 1997a). Percent survival of planted oak did not differ between treatments in either year, whereas that of ash and maple was much less $(p \leq 0.05)$ on burn than control plots in both years. Post-fire survival was not related to plant origin (nursery versus forest grown) or initial mass.

\section{Growth of planted and extant regeneration}

In the absence of fire, ash grew the most among the three species in both regeneration types during the 2-year study (Fig. 1). In the extant population, oak growth was intermediate between that of ash and maple, whereas among planted individuals, oak grew $31-38 \%$ less $(p \leq 0.05)$ than both competitors. The cumulative impact of repeated burning on net relative growth varied considerably among species but was consistent across regeneration types (Fig. 1). Fire decreased the net 2year growth of maple by $45-85 \%(p \leq 0.05)$ and that of ash by $24-37 \%(p \leq 0.05)$. Fire did not alter the growth of oak, and consequently on burn plots it was similar to that of ash and more than double that of maple $(p \leq 0.05)$. Across treatments, planted individuals generally grew less than extant regeneration during the 2 years.

Species variation in net growth response to fire resulted from differences in (1) the percentage of initial plant mass destroyed by fire each year and (2) the extent to which this loss was offset by the rate of post-fire regrowth (actual RGR). Across regeneration types, the average loss of initial mass was $40 \%$ for maple, $35 \%$ for ash, and $28 \%$ for oak in 1989 , whereas it was $10-20 \%$ for all species in 1990 (data not shown). Oak was able to fully compensate for comparatively modest initial losses because its actual RGR on burn plots was higher than its control RGR, particularly in 1990 (Fig. 2). In contrast, the post-fire regrowth of maple was insufficient to compensate for a relatively large loss of initial mass, as its actual RGR on burn plots was never higher, and in one instance (planted maple in 1990) was significantly lower, than its control RGR. The actual RGR of planted individuals was $31-61 \%$ lower than that of their extant counterparts in 1989, but growth rates of the two types tended to converge somewhat in 1990 (Fig. 2).
Fig. 1. Cumulative measures of net relative growth for extant and planted ash, oak, and maple regeneration on burn and control plots during the 2-year study. Net growth was calculated on the basis of initial pre-burn mass in 1989 and final mass in the fall of 1990. Fisher's least significant differences (LSD, $p=0.05$ ) are provided for comparing means within ( $\left.\mathrm{LSD}_{\mathrm{WT}}\right)$ and across $\left(\mathrm{LSD}_{\mathrm{AT}}\right)$ treatments.

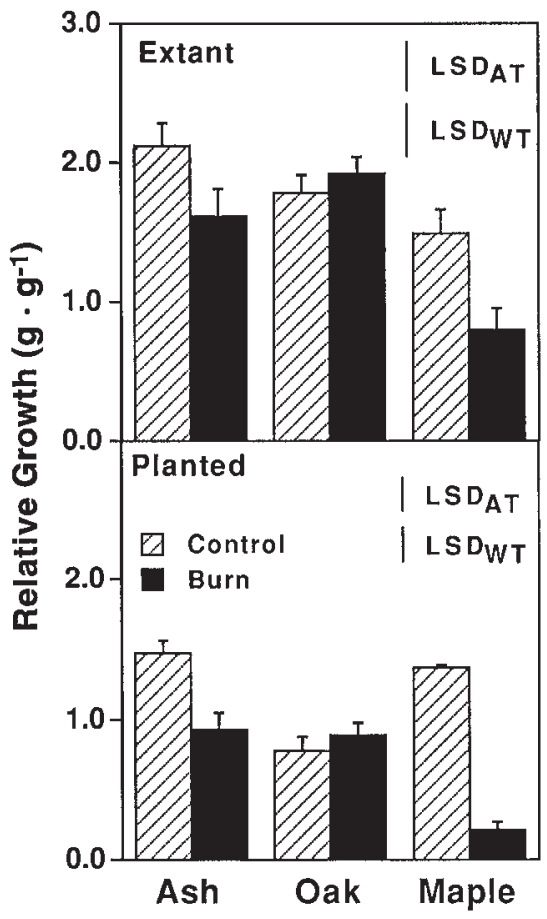

\section{Biomass distribution to leaves}

Species also responded differently to fire in terms of biomass distribution to leaves (Fig. 3). The leaf weight ratio (LWR) of planted maple was 55\% lower $(p \leq 0.05)$ on burn than control plots, with a smaller difference $(p \leq 0.05)$ occurring in extant maple. The opposite effect was observed for planted $(p=0.06)$ and extant oak $(p \leq 0.05)$, as well as planted ash $(p \leq 0.05)$. On control plots maple had the highest LWR in both regeneration types, and the LWR of extant regeneration was generally higher than that of planted regeneration. This difference between types coincided with the tendency of extant regeneration to exhibit recurrent or indeterminate shoot growth (Kruger and Reich 1997a), whereas, especially in the case of control oak and ash, the majority of planted individuals produced only one shoot flush.

\section{Dynamics in tissue nonstructural carbohydrates}

On average, whole-plant TNC concentrations at the beginning of the 1989 growing season (pre-burn) were the highest observed for nonburned regeneration during the study, and they did not vary significantly among species or, with the exception of maple, between origins (Fig. 4). The initial TNC concentration of nursery maple was $38 \%$ less $(p \leq 0.05)$ than that of forest-grown maple. Across species and regeneration types, variation in the percent of initial TNC content lost to fire paralleled losses of initial mass (data not shown). Estimated removals ranged from 12 to $23 \%$ in 1989 , with oak losing less than maple and ash. Losses in 1990 averaged $10 \%$ and did not 
Fig. 2. Relative growth rates (RGR) of extant and planted ash, oak, and maple regeneration on burn and control plots in 1989 and 1990 . Actual RGR on burn plots was calculated using an initial post-fire mass adjusted for stem loss. Net RGR was calculated on the basis of initial pre-burn mass. Fisher's least significant differences (LSD, $p=0.05)$ are provided for comparing means within $\left(\mathrm{LSD}_{\mathrm{WT}}\right)$ and across $\left(\mathrm{LSD}_{\mathrm{AT}}\right)$ treatments.

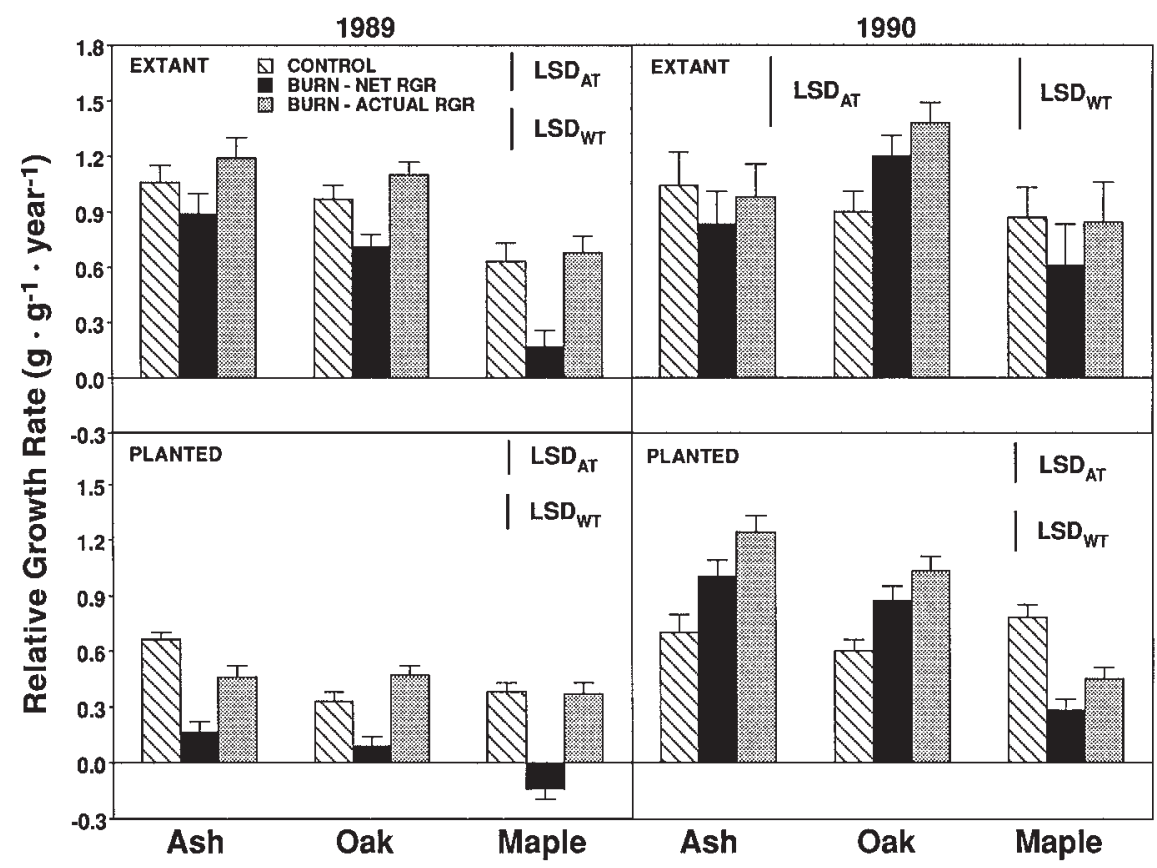

Table 2. $\mathrm{N}$ status of planted regeneration in 1990, including plant $\mathrm{N}$ concentration $([\mathrm{N}], \%)$ in the spring and fall, the ratio of fall [N]/spring [N], and percent $\mathrm{N}$ retranslocation from senescing foliage in the fall.

\begin{tabular}{llllll}
\hline Species & Treatment & $\begin{array}{c}\text { Spring plant } \\
{[\mathrm{N}](\%)}\end{array}$ & $\begin{array}{c}\text { Fall plant } \\
{[\mathrm{N}](\%)}\end{array}$ & $\begin{array}{c}\text { Fall/spring } \\
{[\mathrm{N}] \text { ratio }}\end{array}$ & $\begin{array}{c}\% \mathrm{~N} \\
\text { retranslocation }\end{array}$ \\
\hline Ash & Control & $1.20(0.15) a$ & $0.86(0.04) b$ & $0.72(0.06) \mathrm{c}$ & $28(4) c$ \\
& Burn & $1.23(0.11) a$ & $1.01(0.08) \mathrm{ab}$ & $0.83(0.03) b c$ & $49(3) b$ \\
Oak & Control & $0.93(0.03) a$ & $0.92(0.04) b$ & $0.99(0.05) a$ & $68(3) a$ \\
& Burn & $1.02(0.09) a$ & $0.91(0.10) b$ & $0.90(0.07) a b$ & $57(4) b$ \\
Maple & Control & $1.09(0.18) a$ & $0.82(0.06) b$ & $0.76(0.03) c$ & $32(2) c$ \\
& Burn & $1.26(0.06) a$ & $1.12(0.06) a$ & $0.90(0.06) a b$ & $54(3) \mathrm{b}$ \\
\hline
\end{tabular}

\footnotetext{
Note: Values are species $\times$ treatment means (with their standard errors). Within columns, means without common letters are significantly different $(p \leq 0.05)$.
}

differ significantly among species or between regeneration types. In both years, relative losses of TNC content were $40-60 \%$ less than those of mass because fire removed comparatively TNC-poor stems (Fig. 5). Consequently, while fire destroyed stem TNC reserves, it also effected an immediate $12-23 \%$ increase in whole-plant TNC concentration.

In 1990, spring TNC concentrations in extant regeneration did not differ significantly between treatments (Fig. 4). However, fire had a significant positive effect on the TNC levels of planted individuals at both the onset and end of the 1990 growing season (Figs. 4 and 5). This resulted in part from an increase in the proportion of the post-fire resprout comprising the TNC-rich root system, and, especially in maple, from a large increase in root starch concentration (Fig. 5). The increase in maple TNC was such that species carbohydrate levels were nearly identical on burn plots in fall 1990 (Figs. 4 and 5). Throughout the study, oak possessed the highest root and wholeplant starch concentrations in both treatments (Figs. 4 and 5).

\section{Plant $\mathbf{N}$ relations}

Fire removed $9-14 \%$ of plant $\mathrm{N}$ content in 1990, and the per- centage did not vary significantly among species or regeneration types (data not shown). Despite this loss, whole-plant $\mathrm{N}$ concentrations on burn plots were as high or higher than those on control plots in the fall of that year (Table 2). Overall, plant $\mathrm{N}$ concentration decreased with an increase in plant mass, but the decline was less on burn than contol plots for ash and maple, as was evident in treatment differences in the ratio of fall [N] to spring [N] (Table 2). The percentage of $\mathrm{N}$ retranslocated from senescing foliage also differed between treatments for ash and maple (Table 2). Less than a third of the $\mathrm{N}$ content was retranslocated from leaves of the two species on control plots, but the amount improved to $49-54 \%(p \leq 0.05)$ on burn plots. Among species and treatments, percent retranslocation was highest $(68 \%)$ from oak leaves on control plots. The ratio of fall [N] to spring $[\mathrm{N}]$ was positively correlated with $\mathrm{N}$ retranslocation, where $[\mathrm{N}]_{\text {Fall }} /[\mathrm{N}]_{\text {Spring }}=0.56+0.61(\%$ retranslocation $), r^{2}=0.86$, $p<0.0001(n=24)$.

Species and treatment variation in net and total $\mathrm{N}$ uptake (Table 3) generally paralleled that in actual RGR in 1990. NUE was significantly higher on burn than control plots, but treatment effects on the components of NUE differed among 
Fig. 3. Leaf weight ratio (LWR) of extant and planted ash, oak, and maple regeneration on burn and control plots in 1990. LWR was directly measured and estimated, respectively, for extant and planted individuals on two occasions. However, LWR did not differ significantly between measurement dates, and thus the data were pooled across dates. Fisher's least significant differences (LSD, $p=$ $0.05)$ are provided for comparing means within $\left(\mathrm{LSD}_{\mathrm{WT}}\right)$ and across $\left(\mathrm{LSD}_{\mathrm{AT}}\right)$ treatments.

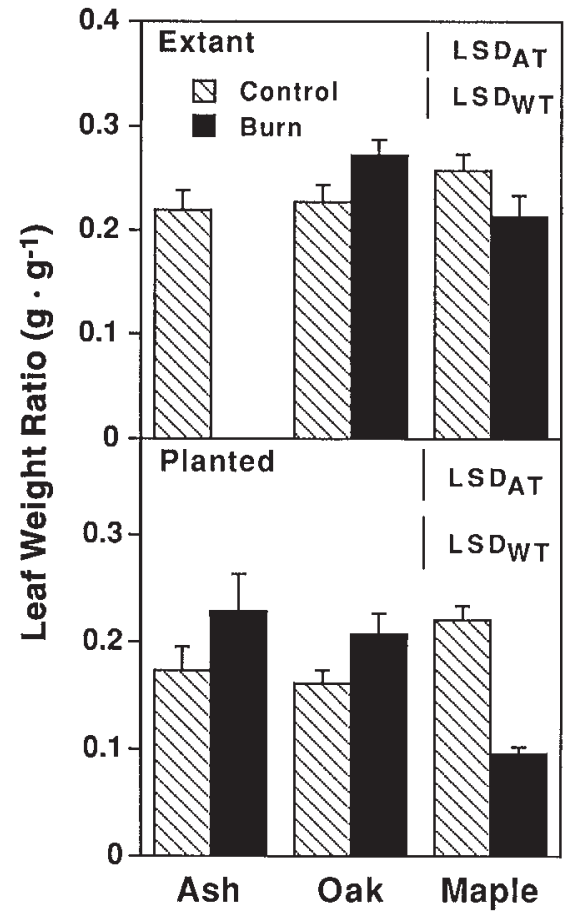

species (Table 3). In the case of ash and oak, production efficiency (PE) increased considerably on burn plots, whereas for maple a large increase in mean residence time (MRT) more than offset the decrease in PE on burn plots. In general there was a negative correspondence between MRT and the percent of $\mathrm{N}$ uptake lost in leaf litter (Table 3).

\section{Relationships between growth and its determinants}

Among the growth determinants tested, including LWR, SLA, leaf area ratio (LAR), and leaf photosynthesis $\left(A_{\max }\right.$ and $A_{\text {avg }}$ ) expressed on both an area and mass basis, only LWR was correlated with actual RGR (Fig. 6). However, actual RGR was also strongly and positively related to light-saturated whole-plant photosynthesis $\left(\mathrm{WPP}_{\max }\right)$, which was the product of $A_{\max }$, LWR, and SLA (Fig. 6). Moreover, the substitution of $A_{\text {avg }}$ for $A_{\text {max }}$ in this product further improved its predictive ability, as $\mathrm{WPP}_{\text {avg }}\left(A_{\mathrm{avg}} \times \mathrm{LWR} \times \mathrm{SLA}\right)$ explained $94 \%$ of the variation in RGR (Fig. 6). WPP avg was a better growth predictor than $\mathrm{WPP}_{\max }$ from an absolute as well as relative standpoint. The agreement between actual RGR and that estimated from either $\mathrm{WPP}_{\text {max }}$ or $\mathrm{WPP}_{\text {avg }}$ was compared using two assumptions: (1) WPP accurately reflected plant behavior for most of the growing season (Kruger and Reich 1997b) and (2) about $0.6 \mathrm{~g}$ of $\mathrm{C}$ was required to build $1 \mathrm{~g}$ of biomass (Poorter 1994). After modifying RGR to include estimates of leaf litter mass, predicted biomass gains overshot actual RGRs by $140-190 \%$ based on $\mathrm{WPP}_{\max }$, but only about $20 \%$ based on $\mathrm{WPP}_{\mathrm{avg}}$ (data not shown).
Fig. 4. Whole-plant concentrations of total nonstructural carbohydrate (TNC) in nursery and forest-grown regeneration prior to fire in the spring of 1989, and in extant and planted regeneration on burn and control plots prior to fire in the spring of 1990. TNC values are partitioned into sugar and starch components, but standard errors pertain only to the TNC mean. Fisher's least significant differences (LSD, $p=0.05)$ are provided for comparing TNC means within ( $\left.\mathrm{LSD}_{\mathrm{WT}}\right)$ and across $\left(\mathrm{LSD}_{\mathrm{AT}}\right)$ treatments. Planted and extant data were analyzed separately in spring 1990.

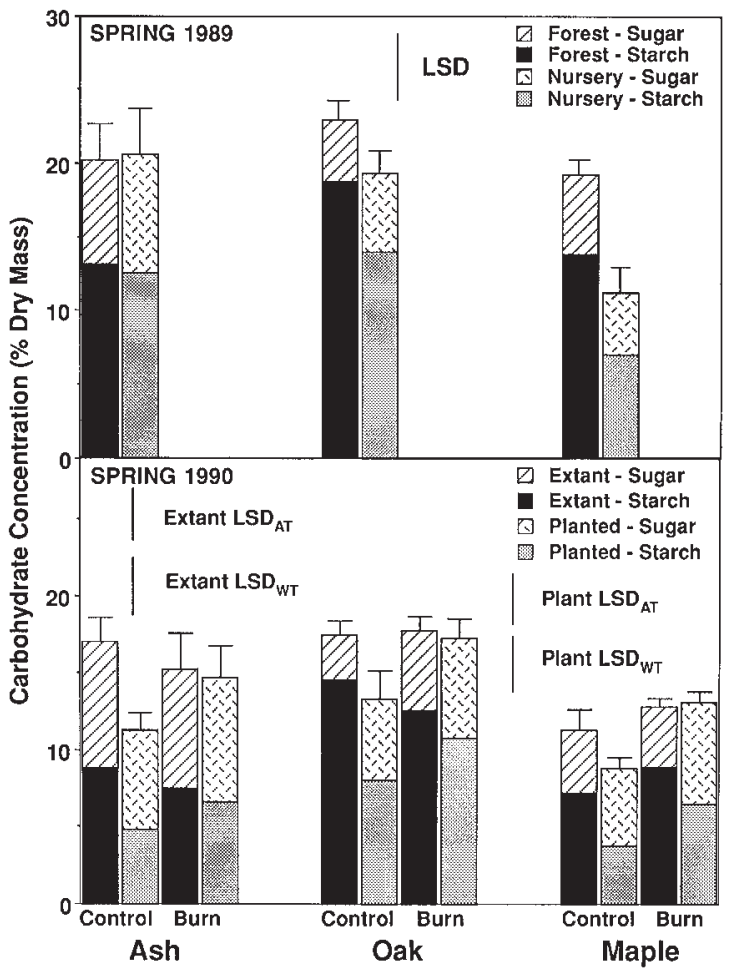

For the most part, trends in TNC concentration were consistent with those in growth in 1990. For example, extant regeneration grew faster (Fig. 2) and possessed higher spring TNC concentrations (Fig. 4) than planted individuals on control plots. Correspondingly, across species, treatments, and regeneration types, actual RGR in 1990 was significantly and positively related to post-fire TNC concentrations in the spring of that year (Fig. 6).

\section{Discussion}

Repeated spring burning in mesic forest openings had little impact on the net growth of northern red oak regeneration, but it adversely affected that of two common competitors, sugar maple and white ash. This enhancement of oak's competitive status was a potentially important benefit given that the density of regeneration was still fairly high ( $>24000$ individuals/ha) on burn plots after the second fire (Kruger and Reich 1997a). In the absence of fire, it was uncertain whether oak would maintain a dominant or codominant position in the developing canopy. Extant oak grew as rapidly as ash and maple on average, but height growth data (Kruger and Reich 1997a) indicated that because of the abundance of maple in particular (150 000 individuals/ha), even the fastest growing oaks were outnumbered (as much as 17:1) by faster growing trees. The low RGR 
of planted oak did not portend well for its future without competition control.

Species growth responses to fire varied because fire differentially affected two key growth determinants, LWR and leaf photosynthesis. Of these only LWR was correlated with RGR, largely because trends in photosynthesis and SLA across species tended to offset one another (Kruger and Reich 1997b). However, the importance of LWR, photosynthesis, and SLA as codeterminants of growth was manifested by the strong relationship between RGR and whole-plant photosynthesis. RGR should relate closely to whole-plant photosynthesis if variation in other carbon balance components, such as maintenance respiration and tissue construction costs, is relatively small (Lambers and Poorter 1992). This often seems to be the case (e.g., Loach 1970; Poorter et al. 1990; Walters et al. 1993), although there are exceptions (e.g., Peng et al. 1993). In elucidating the causes for growth variation, there was a clear need to adjust photosynthesis according to the light environment that typified our forest openings. This resulted in a reasonably accurate prediction of actual biomass gain during the 1990 growing season. Indeed, the $20 \%$ excess in the predicted value might have represented $\mathrm{C}$ allocation to maintenance respiration, mycorrhizae, and other $\mathrm{C}$ losses (Poorter and Lambers 1992).

The linear relationship between actual RGR and $\mathrm{WPP}_{\text {avg }}$ indicated that LWR, SLA, and $A_{\text {avg }}$ each exerted a constant and proportional influence on RGR. This allowed us to resolve the causes for growth differences in a straightforward manner. For example, extant maple grew as rapidly as extant oak on control plots in 1990 because, despite having a 41\% lower $A_{\text {avg }}$, maple possessed a $13 \%$ higher LWR and a $41 \%$ higher SLA than oak. For post-fire sprouts of both extant and planted oak, growth enhancements resulted largely from an increase in LWR. Moreover, planted maple grew slowly on burn plots because the fire-induced stimulation (30\%) in $A_{\text {avg }}$ did not fully compensate for a $55 \%$ decrease in LWR. In contrast, the two attributes more or less counterbalanced one another in the case of extant maple. For all species, planted individuals grew more slowly than extant regeneration on control plots because the former had lower LWRs.

Among the effects of fire in mesic forest openings, top kill itself may have had the most important ramifications for postfire regrowth and its determinants. For example, in the case of oak, elimination of a resource-poor stem may have led to an increase in LWR and RGR because the loss of nonleaf mass was accompanied by a minimal decrease in the nutrient and carbohydrate reserves used for canopy development. In contrast, top kill somehow impaired the production of foliage by maple resprouts. This coincided with an increase in light-saturated leaf photosynthesis, which in turn was associated with an increase in the ratio of projected root area to leaf area brought about by the decrease in canopy mass (Kruger and Reich 1997b).

The extent to which growth was influenced by treatment differences in microenvironment or soil resource availability was unclear. In contrast with observations in other ecosystems (Christensen 1987; Raison 1979), fire did not have a discernible influence on soil N mineralization in this study (Kruger and Reich 1997b). But there were indications of a modest fireinduced increase in soil $\mathrm{NO}_{3}{ }^{-}$availability, perhaps resulting from decreases in vegetation density (Kruger and Reich
Fig. 5. Whole-plant, root, and stem concentrations of total nonstructural carbohydrate (TNC) for planted individuals harvested in the fall of 1990. TNC values are partitioned into sugar and starch components, but standard errors pertain only to the TNC mean. Fisher's least significant differences (LSD, $p=0.05$ ) are provided for comparing TNC means within ( $\left.\mathrm{LSD}_{\mathrm{WT}}\right)$ and across $\left(\mathrm{LSD}_{\mathrm{AT}}\right)$ treatments. Root and stem TNC data were analyzed separately.

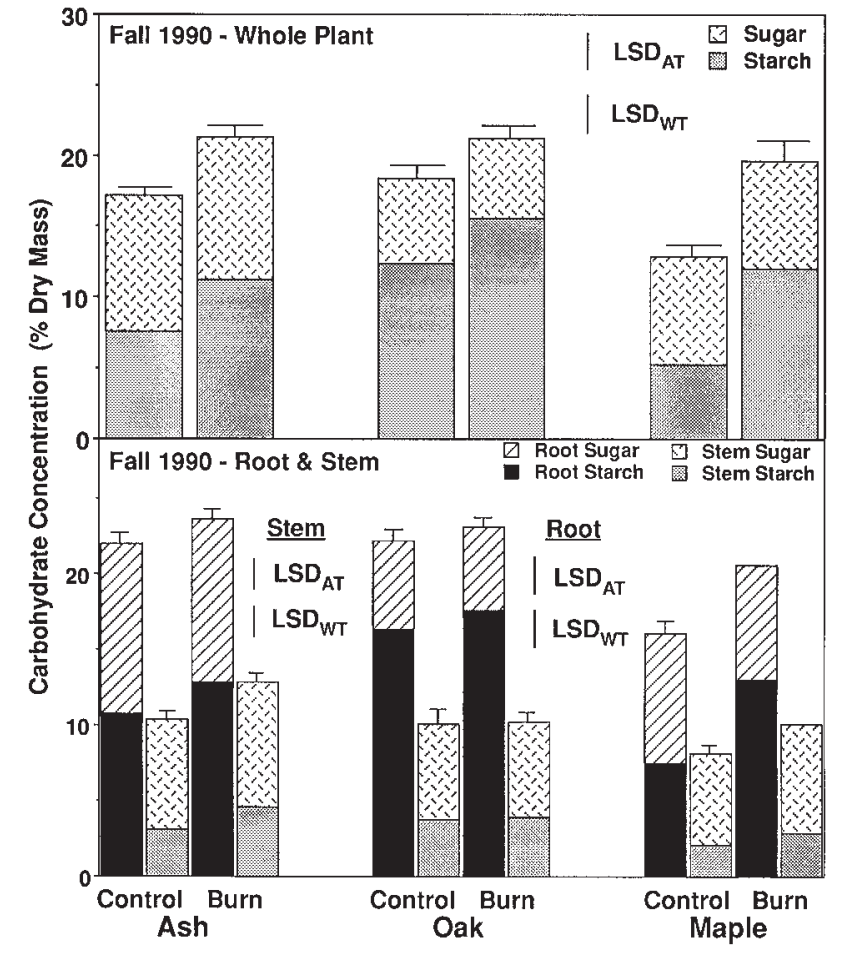

1997a). Soil $\mathrm{NO}_{3}{ }^{-}$concentration has been found to increase slightly after fire on other mesic hardwood sites in southwestern Wisconsin (Knighton 1977). The increases in foliar N concentration (Kruger and Reich 1997b) and LWR observed in this study are typical responses to an increase in soil $\mathrm{N}$ availability (Phares 1971; Walters and Reich 1989; Burton and Bazzaz 1995; Dillenburg et al. 1995).

Other than causing initial losses in resource capital, burning had a neutral or positive influence on plant $\mathrm{N}$ and TNC reserves. Positive effects on plant $\mathrm{N}$ status were associated with increases in the efficiency of $\mathrm{N}$ retranslocation from senescing foliage, which in turn coincided closely with increases in the seasonal average for leaf $\mathrm{N}$ concentration (Kruger and Reich $1997 b$ ). Several studies have documented a positive relationship between $\mathrm{N}$ retranslocation efficiency and the average or maximum $\mathrm{N}$ concentration in green foliage of woody species (e.g., Chapin and Kedrowski 1983; Reich et al. 1995). The implications of changes in $\mathrm{N}$ retranslocation were evident in several aspects of plant $\mathrm{N}$ economy, including NUE and MRT. Fire also altered root $\mathrm{N}$ uptake, but the effect varied among species and may have been a consequence rather than a cause of treatment and species differences in growth. In fact, trends in PE indicated that growth was coupled less to the amount of $\mathrm{N}$ in the plant than to the rate of $\mathrm{C}$ assimilation per unit plant $\mathrm{N}$. The latter corresponded more closely to LWR than to leaf photosynthesis (Kruger and Reich 1997b).

Growth variation across treatments, species, and regeneration types may have been coupled in part with plant carbohydrate 
Fig. 6. Relationships between actual RGR and LWR, whole-plant photosynthesis, or spring (post-fire) TNC concentration in 1990. Individual data are treatment $\times$ species means for each regeneration type. Open symbols represent control means for extant $(\triangle)$ and planted ash $(\triangle)$, extant $(\bigcirc)$ and planted oak $(\odot)$, and extant $(\square)$ and planted maple $(\bullet)$. Solid symbols represent burn means for extant $(\boldsymbol{\Delta})$ and planted ash $(\mathbf{\Delta})$, extant $(\boldsymbol{\bullet})$ and planted oak $(\bullet)$, and extant $(\boldsymbol{\square})$ and planted maple $(\boldsymbol{\bullet})$. Post-fire TNC concentrations differed from corresponding pre-burn values in Fig. 4 in that they were adjusted for stem destruction by fire.

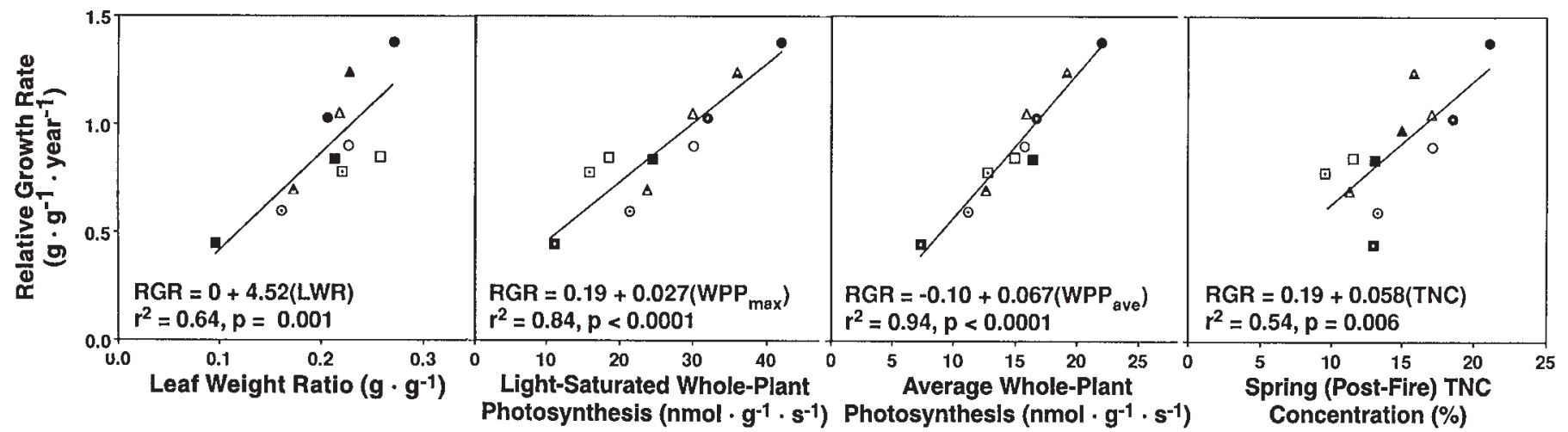

Table 3. $\mathrm{N}$ economy of planted regeneration in 1990, including net and total $\mathrm{N}$ uptake $\left(\mathrm{mg} \mathrm{N} \cdot(\mathrm{g} \text { root })^{-1}\right)$, percent of total $\mathrm{N}$ uptake lost in leaf litter, production efficiency (PE, g biomass gain $\cdot(\mathrm{g} \mathrm{N})^{-1} \cdot \mathrm{year}^{-1}$ ), mean residence time of $\mathrm{N}$ in the plant (MRT, year), and $\mathrm{N}$-use efficiency (Aerts 1990, NUE $=\mathrm{PE} \times \mathrm{MRT})$.

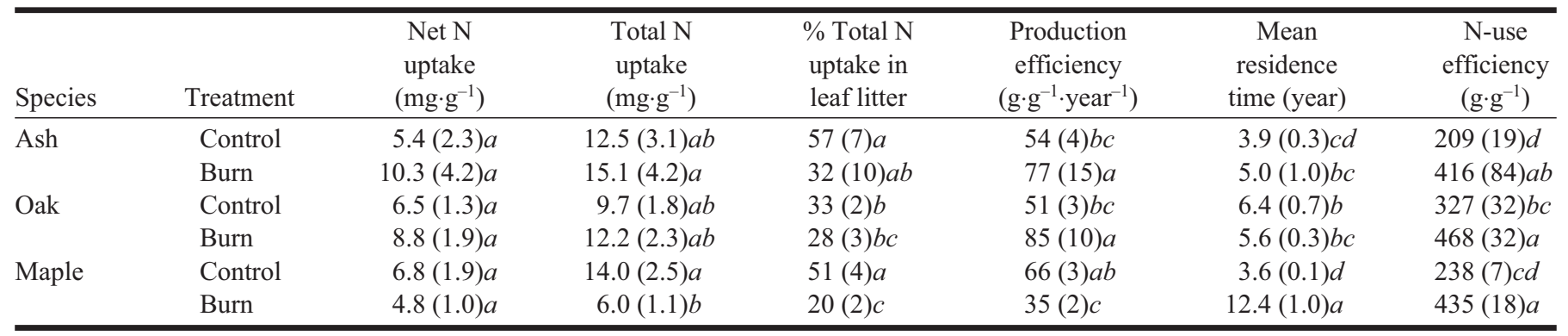

Note: Total $\mathrm{N}$ uptake included canopy $\mathrm{N}$ content lost in fall leaf litter, while net uptake did not. Values are species $\times$ treatment means (with their standard errors). Within columns, means without common letters are significantly different $(p \leq 0.05)$.

status. Spring TNC reserves fuel initial foliage production and growth of deciduous woody species in temperate forests (Kozlowski and Keller 1966), and at least within species, variation in growth has been linked with that in carbohydrate status (e.g., Kays and Canham 1991; Kruger and Reich 1993). However, although RGR and spring TNC reserves were positively correlated in 1990, the relationship contained glaring inconsistencies, particularly with respect to maple. For instance, among planted regeneration maple had the lowest TNC concentration but grew the fastest of the three species on control plots. Moreover, high spring TNC concentrations preceded comparatively slow growth by maple on burn plots, especially in the case of planted individuals. In general, one would not necessarily expect a strong tie between spring TNC reserves and RGR, especially across species, because TNC status is only one of a wide array of plant traits that influence growth rate. Nevertheless, among species with considerable overlap in physiological and allocational characteristics, such as oak and ash in our study, initial carbohydrate status may play a critical role in growth variation.

The link between growth and carbohydrate status may have been confounded by species differences in phenology. TNC concentrations in sugar maple typically decline to minimal levels during the spring in northern temperate forests (Wargo 1971; Burke et al. 1992), and this depletion coincides with early bud break and rapid canopy development. If critical carbohydrate or nutrient reserves had already been invested in bud expansion by the time of the fire, top kill in the spring might have left maple without the full resources needed to replace the canopy. On the other hand, maple's post-fire growth may not have been constrained by carbohydrate status, but rather by a dearth of surviving dormant buds with which to rebuild the canopy. This possibility was supported by the nature and extent of maple mortality on burn plots (Kruger and Reich 1997a), as many individuals failed altogether to sprout after fire. It would also be consistent with evidence that low-intensity fires during the dormant season can cause substantial mortality of maple regeneration (Anderson 1983). Furthermore, it would help reconcile the discrepancy between our findings and observations (e.g., MacDonald and Powell 1985) that sugar maple often sprouts vigorously from the stump after coppicing in the spring. Sugar maple stems typically possess a large number of dormant buds (Church and Godman 1966), but it is uncertain how many of these are normally found at or beneath the soil surface in young trees.

We planted trees in order to directly measure biomass growth, with the anticipation that measured trends would be representative of those occurring in extant regeneration. For the most part, this held true for growth, leaf function, phenology, biomass distribution, and fire-induced mortality. Overall, 
the most apparent difference between the two regeneration types was growth rate, particularly in the case of oak. A protracted transplant response was evidenced not only by slow growth but also by low carbohydrate reserves and was associated with a failure of planted individuals to recover LWRs comparable with those of extant regeneration. The results of this study support the conclusions of Struve and Joly (1992) that damage to fine roots during transplanting leads to a decrease in subsequent allocation to leaf mass. This may often be a primary cause of the poor performance of bare-root oak seedlings, even in the favorable conditions of a mesic forest opening (Johnson 1976; Farmer 1981; Beck and Hooper 1986).

Collectively, the results of this study provided clear linkages between the growth rate and physiological attributes of hardwood tree regeneration in mesic, high-light forest environments. As has been observed in controlled environments (Loach 1970; Farmer 1980; Walters et al. 1993), tree growth rate in a natural setting was governed by no single attribute (Poorter et al. 1990), but rather by a combination of physiological, morphological, and allocational characteristics. Moreover, key traits were seen to vary in accord with intrinsic (e.g., root area/leaf area ratio) as well as extrinsic factors controlling resource availability to the plant (Walters and Reich 1989; Millard and Proe 1991; Kruger and Reich 1993; Burton and Bazzaz 1995; Dillenburg et al. 1995). For reasons that were not entirely clear, northern red oak was able to reestablish a large canopy and grow rapidly after fire, whereas sugar maple was not. The difference in response did not relate directly to fire effects on internal resource balance, but it did correspond to overall species variation in tissue carbohydrate reserves, as oak generally possessed higher starch concentrations than ash or maple. Such a link between carbohydrate reserves and post-fire vigor would be consistent with the view that certain characteristics of oak, such as a high root starch concentration, are adaptations to severe disturbances (Crow 1988). However, some of oak's other attributes, such as an abundance of belowground dormant buds, may be as or more critical for post-fire recovery.

\section{Acknowledgments}

We are very grateful to Rachel and Don Jordan for letting us conduct this project in the Jordan Timberland, and for their continuing support of oak ecology research. Financial support was provided by the Elmer G. Biddick Foundation, The Nature Conservancy, The University of Wisconsin-Madison, and the USDA Competitive Grants Program (CRGO-USDA 9037290-5686). We also thank John Bliss, David Ellsworth, Ron Gropp, John Volin, Dirk Vanderklein, Mike Walters, and Beth Wertschnig for their assistance in various aspects of the study. We are particularly indebted to Brian Kloeppel for his invaluable help throughout the project.

\section{References}

Abrams, M.D. 1992. Fire and the development of oak forests. BioScience, 42: 346-353.

Aerts, R. 1990. Nutrient use efficiency in evergreen and deciduous species from heathlands. Oecologia, 84: 391-397.

Amundson, R.G., Kohut, R.J., and Laurence, J.A. 1995. Influence of foliar $\mathrm{N}$ on foliar soluble sugars and starch of red spruce saplings exposed to ambient and elevated ozone. Tree Physiol. 15: $167-174$.

Anderson, H.W. 1983. Regenerating yellow birch with prescribed fire. In Proceedings, America's Hardwood Forests - Opportunities Unlimited, 1982 Convention of The Society of American Foresters, 19-22 Sept., Cincinnati, Ohio. Society of American Foresters, Washington, D.C. pp. 168-172.

Bazzaz, F. 1979. The physiological ecology of plant succession. Annu. Rev. Ecol. Syst. 10: 351-371.

Beck, D.E., and Hooper, R.M. 1986. Development of a southern Appalachian hardwood stand after clearcutting. South. J. Appl. For. 10: $168-172$.

Braun, E.L. 1950. Deciduous forests of eastern North America. MacMillan Publishing Company, New York.

Brown, J.H. 1960. The role of fire in altering the species composition of forests in Rhode Island. Ecology, 41: 310-316.

Burke, M.K., Raynal, D.J., and Mitchell, M.J. 1992. Soil nitrogen availability influences seasonal carbon allocation patterns in sugar maple (Acer saccharum). Can. J. For. Res. 22: 447-456.

Burton, P.J., and Bazzaz, F.A. 1995. Ecophysiological responses of tree seedlings invading different patches of old-field vegetation. J. Ecol. 83: 99-112.

Busch, D.E., and Smith, S.D. 1993. Effects of fire on water and salinity relations of riparian woody taxa. Oecologia, 94: 186-194.

Chapin, F.S., and Kedrowski, R.A. 1983. Seasonal changes in nitrogen and phosphorous fractions and autumn retranslocation in evergreen and deciduous taiga trees. Ecology, 64: 376-391.

Christensen, N.L. 1987. The biogeochemical consequences of fire and their effects on the vegetation of the coastal plain of the southeastern United States. In The role of fire in ecological systems. Edited by L. Trabaud. Academic Publishing, The Hague, Netherlands. pp. 1-21.

Church, T.W., and Godman, R.M. 1966. The formation and development of dormant buds in sugar maple. For. Sci. 12: 301-306.

Crow, T.R. 1988. Reproductive mode and mechanisms for selfreplacement of northern red oak (Quercus rubra) - a review. For. Sci. 34: 19-40.

Dillenburg, L.R., Teramura, A.H., Forseth, I.N., and Whigham, D.F. 1995. Photosynthetic and biomass allocation responses of Liquidambar styraciflua (Hamamelidaceae) to vine competition. Am. J. Bot. 82: 454-461.

Evans, C.G. 1972. The quantitative analysis of plant growth. University of California Press, Berkeley.

Farmer, R.E. 1980. Comparative analysis of $1^{\text {st }}$ year growth in six deciduous tree species. Can. J. For. Res. 10: 35-41.

Farmer, R.E. 1981. Early growth of black cherry, oaks, and yellowpoplar in southern Appalachian plantings. Tree Plant. Notes, 32: $12-14$.

Hanson, P.J., Isebrands, J.G., Dickson, R.E., and Dixon, R.K. 1988. Ontogenetic patterns of $\mathrm{CO}_{2}$ exchange of Quercus rubra L. leaves during three flushes of shoot growth. I. Median flush leaves. For. Sci. 34: 55-68.

Hole, F.D. 1976. Soils of Wisconsin. University of Wisconsin Press, Madison, Wis.

Johnson, P.S. 1976. Eight-year performance of interplanted hardwoods in southern Wisconsin oak clearcuts. USDA For. Serv. Res. Pap. NC-126.

Johnson, P.S. 1993. Perspectives on the ecology and silviculture of oak-dominated forests in the central and eastern states. USDA For. Serv. Gen. Tech Rep. NC-153.

Kaelke, C.M. 1996. Growth and physiology of northern red oak and competing tree species along a light gradient in mesic hardwood forests of southern Wisconsin. M.S. thesis, University of WisconsinMadison.

Kays, J.S., and Canham, C.D. 1991. Effects of time and frequency of cutting on hardwood root reserves and sprout growth. For. Sci. 37: $524-539$. 
Knighton, D.M. 1977. Hydrologic response and nutrient concentrations following spring burns in an oak-hickory forest. Soil Sci. Soc. Am. J. 41: 627-632.

Kolb, T.E., and Steiner, K.C. 1990. Growth and biomass partitioning of northern red oak and yellow-poplar seedlings: effects of shading and grass root competition. For. Sci. 36: 34-44.

Kozlowski, T.T., and Keller, T. 1966. Food relations of woody plants. Bot. Rev. 32: 293-382.

Kruger, E.L. 1992. Survival, growth and ecophysiology of northern red oak (Quercus rubra) and competing tree regeneration in response to fire and related disturbance. Ph.D. thesis, University of Wisconsin-Madison.

Kruger, E.L., and Reich, P.B. 1993. Coppicing affects growth, root:shoot relations and ecophysiology of potted Quercus rubra seedlings. Physiol. Plant. 89: 751-760.

Kruger, E.L., and Reich, P.B. 1997a. Response of hardwood regeneration to fire in mesic forest openings. I. Post-fire community dynamics. Can. J. For. Res. 27: 1822-1831.

Kruger, E.L., and Reich, P.B. 1997b. Response of hardwood regeneration to fire in mesic forest openings. II. Leaf gas exchange, nitrogen concentration, and water status. Can. J. For. Res. 27: 1832-1840.

Lambers, H., and Poorter, H. 1992. Inherent variation in growth rate between higher plants: a search for physiological causes and ecological consequences. Adv. Ecol. Res. 23: 188-261.

Loach, K. 1970. Shade tolerance in tree seedlings. II. Growth analysis of plants raised under artificial shade. New Phytol. 69: 273-286.

Lorimer, C.G. 1993. Causes of the oak regeneration problem. In Oak regeneration: serious problems, practical recommendations. USDA For. Serv. Gen. Tech. Rep. SE-84. pp. 14-39.

MacDonald, J.E., and Powell, G.R. 1985. First growing period development of Acer saccharum stump sprouts arising after different dates of cut. Can. J. Bot. 63: 819-828.

Meinzer, F.C., and Grantz, D.A. 1990. Stomatal and hydraulic conductance in growing sugarcane: stomatal adjustment to water transport capacity. Plant Cell Environ. 13: 383-388.

Millard, P., and Proe, M.F. 1991. Leaf demography and the seasonal internal cycling of nitrogen in sycamore (Acer pseudoplatanus L.) seedlings in relation to nitrogen supply. New Phytol. 117: 587-596.

Milliken, G.A., and Johnson, D.E. 1989. Analysis of messy data. Chapman and Hall, New York.

Peng, S., Eissenstat, D.M., Graham, J.H., Williams, K., and Hodge, N.C. 1993. Growth depression in mycorrhizal citrus at high-phosphorus supply. Plant Physiol. 101: 1063-1071.
Perala, D.A. 1974. Prescribed burning in an aspen - mixed hardwood forest. Can. J. For. Res. 4: 222-228.

Phares, R.E. 1971. Growth of red oak (Quercus rubra L.) seedlings in relation to light and nutrients. Ecology, 52: 669-672.

Poorter, H. 1994. Construction costs and payback time of biomass: a whole plant perspective. In A wholeplant perspective on carbonnitrogen interactions. Edited by J. Roy and E. Garnier. Academic Publishing, The Hague, Netherlands. pp. 111-127.

Poorter, H., Remkes, C., and Lambers, H. 1990. Carbon and nitrogen economy of 24 wild species differing in relative growth rate. Plant Physiol. 94: 621-627.

Raison, R.J. 1979. Modification of the soil environment by vegetation fires with particular reference to nitrogen transformations: a review. Plant Soil, 51: 73-108.

Reich, P.B., Abrams, M.D., Ellsworth, D.S., Kruger, E.L., and Tabone, T.J. 1990. Fire affects ecophysiology and community dynamics of central Wisconsin oak forest regeneration. Ecology, 71: 2179-2190.

Reich, P.B., Ellsworth, D.S., and Uhl, C. 1995. Leaf carbon and nutrient assimilation and conservation in species of differing successional status in an oligotrophic Amazon forest. Funct. Ecol. 9: $65-76$

SAS Institute Inc. 1988. SAS/STAT user's guide: release 6.03 edition. SAS Institute Inc., Cary, N.C.

Schulte, E.E., Peters, J.B., and Hodgson, P.R. 1987. Wisconsin procedures for soil testing, plant analysis and feed and forage analysis. Soil Fertility Series. No. 6. Department of Soil Science, University of Wisconsin-Extension, Madison, Wis.

Struve, D.K., and Joly, R.J. 1992. Transplanted red oak seedlings mediate transplant shock by reducing leaf surface area and altering carbon allocation. Can. J. For. Res. 22: 1441-1448.

Swan, F.R., Jr. 1970. Post-fire response of four plant communities in south central New York State. Ecology, 51: 1074-1082.

Walters, M.B., and Reich, P.B. 1989. Responses of Ulmus americana seedlings to varying nitrogen and water status. I. Photosynthesis and growth. Tree Physiol. 5: 159-172.

Walters, M.B., Kruger, E.L., and Reich, P.B. 1993. Relative growth rate in relation to physiological and morphological traits for northern hardwood tree seedlings: species, light environment and ontogenetic considerations. Oecologia, 96: 219-231.

Wargo, P.M. 1971. Seasonal changes in carbohydrate levels in roots of sugar maple. USDA For. Serv. Res. Pap. NE-213.

Wellington, A.B. 1984. Leaf water potentials, fire and the regeneration of mallee eucalypts in semi-arid, southeastern Australia. Oecologia, 64: 360-362. 